\title{
Application of monolithic foam concrete in building envelopes of a cottage, used in conditions of intermittent heating
}

\author{
Yuri Vytchikov ${ }^{1}$, Mikhail Saparev ${ }^{1, *}$, and Vladislav Golikov ${ }^{1}$ \\ ${ }^{1}$ Samara State Technical University, Academy of Architecture and Civil Engineering, \\ Molodogvardeyskaya St., 194, Samara, 443001, Russia
}

\begin{abstract}
The paper focuses upon the peculiarities of application of monolithic foam concrete as a heat-insulating layer in building envelopes of houses used in conditions of intermittent heating. The researchers analyze thermal characteristics, review literature describing the application of foam concrete in construction and demonstrate this material applicability at outer walls insulating, taking buildings and constructions with variable thermal behaviour as an example. The paper outlines main criteria that building envelopes of such structures should meet. To assess the effectiveness of monolithic foam concrete in building envelopes application, the authors carried out thermo-technical calculation of the outer walls, insulated with monolithic foam concrete. The graphs of dependence of multilayer building envelope heating time upon thickness of a heat-insulating layer and upon heat transmission resistance of the construction was obtained on the basis of these calculations. The dependence of specific energy consumption upon the heating time is also given in the paper. The study reveals the optimal range of thickness and density of monolithic foam concrete for insulating outer walls of buildings, used in in conditions of intermittent heating. This calculation also proves that the application of foam concrete as an insulant on the inside of the outer wall makes it possible to reduce the load on the building foundation.
\end{abstract}

\section{Introduction}

Building and construction in any country always depend on economic factors and the country's economic situation. Recent crisis developments in Russian economy dictate new terms for industrial and civil construction in this country. The rise in prices for building materials makes customers and contractors look for building materials that meet such important economic efficiency conditions as sustainability and ecological compatibility.

Outdated construction technologies and use of building materials, corresponding to All Union State Standards (GOST) and standards of the USSR, lead to rises in project costs. At the same time, modern construction development aims to facilitate transition from single-

* Corresponding author: msx072007@yandex.ru 
layer structures to multilayer constructions with structural layers having different heat protection and bearing functions.

In other words, there is a need for some universal material for construction of buildings of individual development which is characterized by durability, high heat-insulating ability, durability and fire-protection properties.

Since the thirties of the 20th century in this country there started the growth of production of foamed concrete of autoclave and non-autoclave maturing. Different types of foamed concrete are wide spread and widely used. The researchers have analyzed existing types of foamed concrete and decided that monolithic foam concrete is one of the most effective and popular types.

Monolithic foam concrete is a mixture with evenly distributed closed bubbles fastened among themselves thus providing a reduction in the density of concrete. Due to the variation of its density from 200 to $1600 \mathrm{~kg} / \mathrm{m}^{3}$, monolithic foam concrete can be used not only as a constructive but also as heat insulating soundproof material [1]. Its thermal conductivity coefficient varies from 0.065 to $0.27 \mathrm{~W} /\left(\mathrm{m} \cdot{ }^{\circ} \mathrm{C}\right)$ depending on its density. Its soundproof capacity is 1.5-2 times higher than in the brick walls. Monolithic foam concrete is also characterized by a rather low water absorb-ability.

The environmental characteristics of the material should also be mentioned. Monolithic foam concrete has the 1st degree of fire resistance and reliably thus protecting structures against the spread of fire [2, 3].

This concrete low density and lightness allow to reduce the time of its transportation and laying. It is possible to produce foam concrete both in stationary conditions and directly on a construction site using less energy-consuming non-autoclave technology. It allows to exclude fight, unloading-loading and transportation expenses.

The range of monolithic foam concrete application is extensive, which makes it an excellent material for the construction of buildings and structures which require fast speed of erection and shallow thickness of building envelopes [4]. This material is of great interest for structures with intermittent heat supply [5-7]. These buildings include country cottages, ski resorts, site engineer houses, etc.

\section{Thermo-technical calculation methodology}

Thermal regime of such objects is unsteady, as the basic thermal load is used for maintenance of sanitary-hygienic norms. Peak heat load falls on weekends or holidays, when the temperature must be maintained within the range of $18 \div 26^{\circ} \mathrm{C}$, depending on the region of construction.

Papers [9, 10] present the research results of thermal regime of premises heated periodically. Paper [8] describes the methodology of determining the heating time of building structures.

Thus, the structures for such buildings must meet two important criteria:

$$
R_{0}>R_{\text {req }}
$$

where $R_{0}$ is reduced resistance to the enclosing structure heat transmission resistance, $\left(\mathrm{m}^{2} \cdot{ }^{\circ} \mathrm{C}\right) / \mathrm{W} ; R_{\text {req }}$ - required resistance to the enclosing structure heat transmission resistance, based on sanitary and comfortable conditions, $\left(\mathrm{m}^{2} \cdot{ }^{\circ} \mathrm{C}\right) / \mathrm{W}$.

$$
\tau_{\mathrm{h}}>\tau_{\text {req }}
$$


where $\tau_{\mathrm{h}}$ - heating time of the outer wall, $\mathrm{s} ; \tau_{\text {req }}-$ required time of heating enclosing construction, $\mathrm{s}$.

Paper [10] presents the methodology of multilayer structures calculation [10].

\section{Calculation results}

As an example, let us make thermos-physical calculation of the outer wall, insulated with monolithic foam concrete. The building envelope is made of silicate bricks with $\delta=120$ mm thickness, $\rho=1800 \mathrm{~kg} / \mathrm{m}^{3}$ density; monolithic foam concrete which characteristics vary depending on its density; and plasterboard with $\delta=12.5 \mathrm{~mm}$ thickness and $\rho=800 \mathrm{~kg} / \mathrm{m}^{3}$ density. The detailed diagram of the enclosing structure is shown in Figure 1.

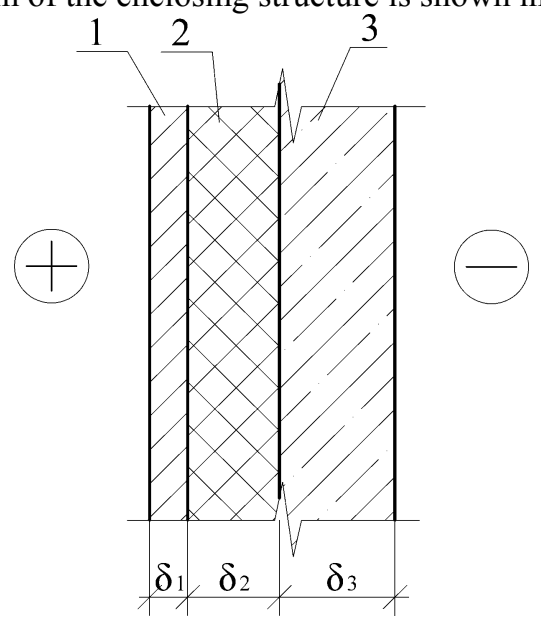

Fig. 1. Brick work construction insulated with monolithic foam concrete from inside: 1 plasterboard $\delta_{1}=0,0125 \mathrm{~m} ; \gamma_{1}=800 \mathrm{~kg} / \mathrm{m}^{3} ; \lambda_{1}=0,19 \mathrm{~W} /\left(\mathrm{m} \cdot{ }^{\circ} \mathrm{C}\right) ; \mathrm{c}_{1}=0,84 \mathrm{~kJ} /\left(\mathrm{kg} \cdot{ }^{\circ} \mathrm{C}\right) ; 2-$ insulating layer of monolithic foam concrete; 3 - brick work of silicate bricks $\delta_{3}=0.12 \mathrm{~m} ; \rho_{3}=1800$ $\mathrm{kg} / \mathrm{m}^{3} ; \lambda_{3}=0,76 \mathrm{~W} /\left(\mathrm{m} \cdot{ }^{\circ} \mathrm{C}\right) ; \mathrm{c}_{3}=0,8 \mathrm{~kJ} /\left(\mathrm{kg} \cdot{ }^{\circ} \mathrm{C}\right)$.

Table 1 summarizes the calculations results. As a result of calculations, the researches obtained dependencies, showing the minimum and maximum values of the enclosing structure thickness, depending on the density of thermal insulation (see Figure 2-4).

Table 1. The results of a building envelope thermo-technical calculation.

\begin{tabular}{|c|c|c|c|}
\hline \multirow[b]{2}{*}{$\begin{array}{l}\text { Density } \rho, \\
\mathrm{kg} / \mathrm{m}^{3}\end{array}$} & \multicolumn{2}{|c|}{ Insulating layer thickness } & \multirow{2}{*}{$\begin{array}{l}\text { Required heat } \\
\text { transmission } \\
\text { resistance } \\
R_{\text {req }},\left(\mathrm{m}^{2} \cdot{ }^{\circ} \mathrm{C}\right) / \mathrm{W}\end{array}$} \\
\hline & $\begin{array}{c}\text { Minimum } \\
\delta_{\min }, \mathrm{m}\end{array}$ & $\underset{\mathrm{m}}{\operatorname{Maximum} \delta_{\max },}$ & \\
\hline 100 & 0.082 & 0.160 & 1.5 \\
\hline 150 & 0.085 & 0.160 & 1.5 \\
\hline 200 & 0.087 & 0.160 & 1.5 \\
\hline 300 & 0.105 & 0.180 & 1.5 \\
\hline 400 & 0.130 & 0.210 & 1.5 \\
\hline 500 & 0.195 & 0.270 & 1.5 \\
\hline 600 & 0.214 & 0.290 & 1.5 \\
\hline 700 & 0.245 & 0.320 & 1.5 \\
\hline 800 & 0.256 & 0.330 & 1.5 \\
\hline 1000 & 0.278 & 0.350 & 1.5 \\
\hline
\end{tabular}




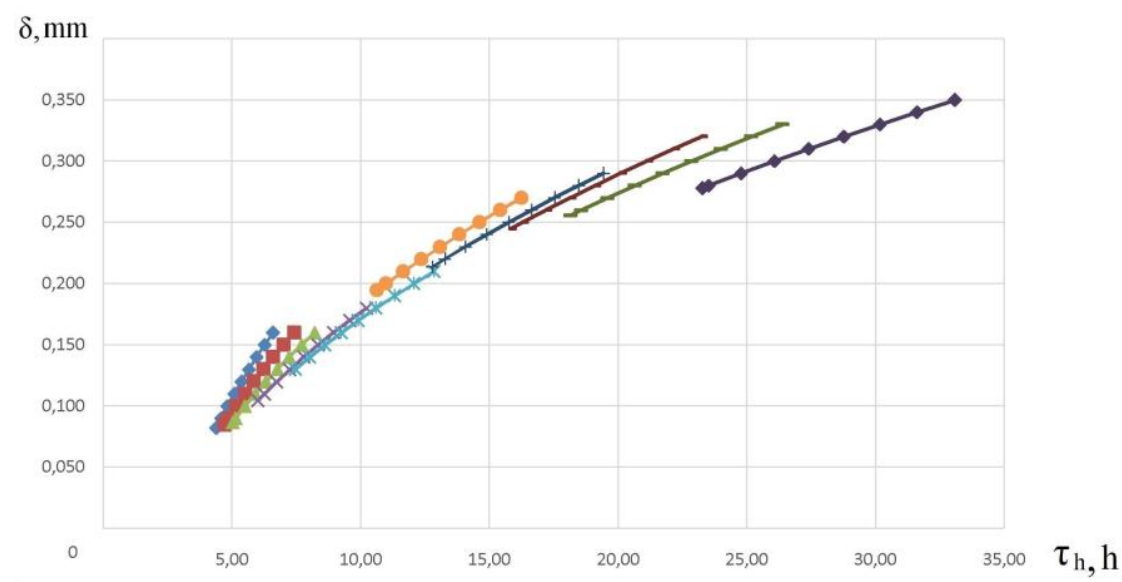

Fig. 2. Dependence of the building envelope heating time on its thermal insulation thickness.

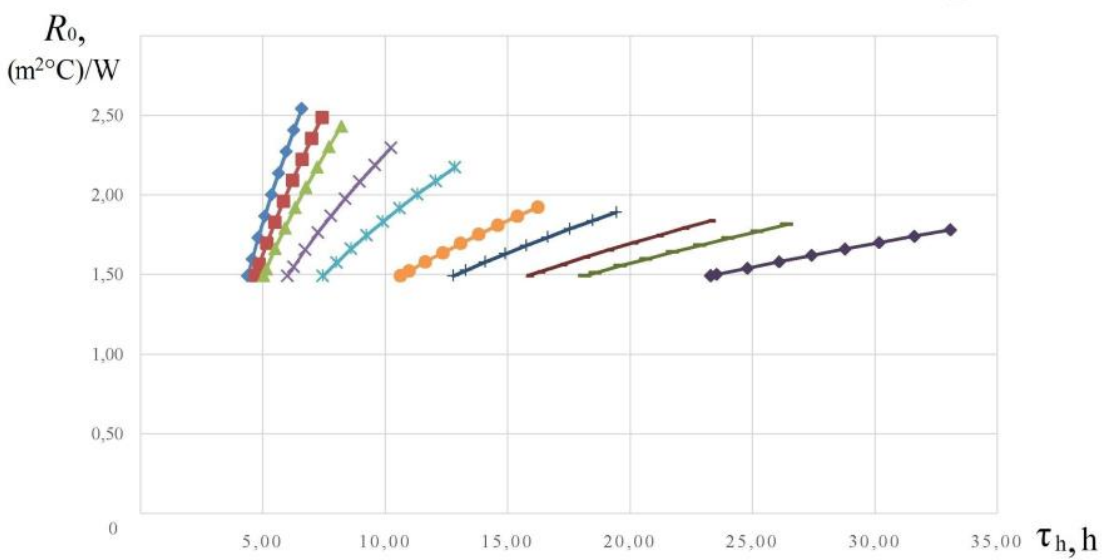

Fig. 3. Dependence of the building envelope heating time on reduced heat transmission resistance.

\section{Discussion}

The calculations showed that monolithic foam concrete density from $\rho=100 \mathrm{~kg} / \mathrm{m}^{3}$ to $\rho=$ $300 \mathrm{~kg} / \mathrm{m}^{3}$ is characterized by the lowest time of heating enclosing construction. Besides, the use of foam concrete with such density due to the low heat conductivity of the material allows to reduce the thickness of the structure and specific energy costs of its heating.

However, it is not possible to completely abandon the use of bricks as a material for erection of such enclosing structures due to the relatively small mechanical strength of foam concrete. Application of such material as an effective thermal insulation is most appropriate in combination with strong structural building materials. 


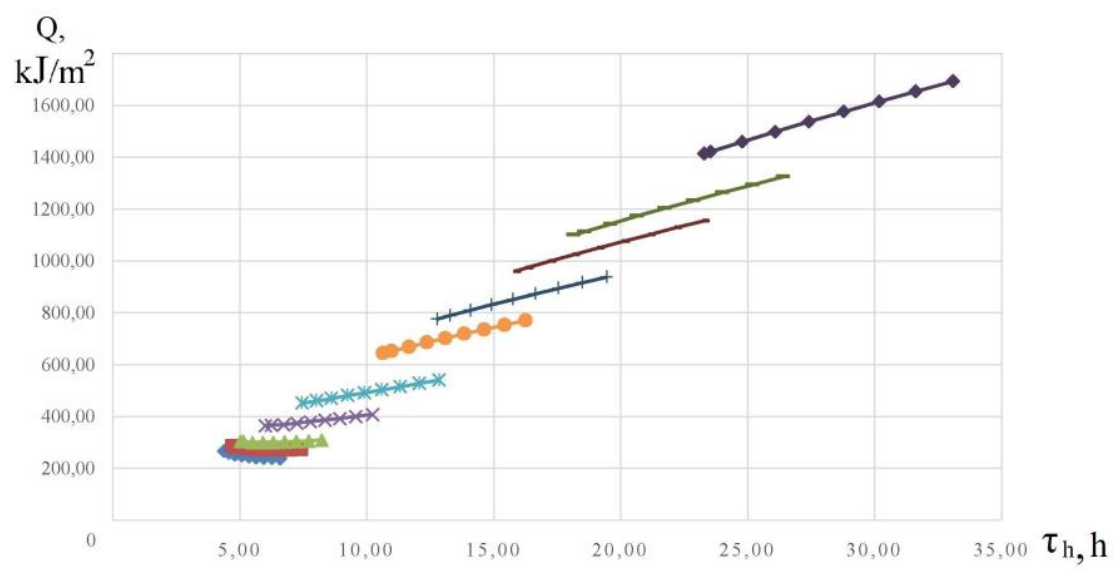

Fig. 4. Dependence of specific energy consumption on the building envelope heating time.

\section{Conclusions}

The thermo-technical calculation of various external walls, insulated with monolithic foam concrete, makes it possible to define the most useful range of this material densities (from 100 to $300 \mathrm{~kg} / \mathrm{m}^{3}$ ) in terms of energy saving. This calculation also showed the applicability of foam concrete as an insulant on the outer wall interior face.

\section{References}

1. D. M. Valevich, V. I. Rimshin, V.L. Kurbatov, Modern technologies: current issues, achievements and innovations: collection of articles of the IX International scientific and practical conference, 50-54 (2017)

2. A.I. Savenkov, P.S. Gorbach, S.A. Sherbin, Collection of scientific works of Angara State Technical University, 1, 1 (2008)

3. A.S. Sergeyev, D.G. Suhorebrov, S.Yu. Pirieva, International scientific and technical conference of young scientists of BGTU, 2513-2517 (2015)

4. A.A. Gaidukov, Alley of Science, 4, 10 (2017)

5. V.I. Panferov, E.Yu. Anisimova, Journal of South Ural State University: Construction and architecture, 12 (112) (2008)

6. E.Yu. Anisimova, Journal of South Ural State University: Construction and architecture, 38 (297) (2012)

7. E.G. Malyavina, R.R. Asatov, Academia. Architecture and construction, 3 (2010)

8. Yu.S. Vytchikov, I.G. Belyakov, M.Ye. Saparev, International Research Journal, 6 (48) (2016)

9. Yu.S. Vytchikov, I.G. Belyakov, M.Ye. Saparev, Procedia Engineering, 153 (2016)

10. Yu.S. Vytchikov, M.Ye. Saparev, A.A. Chulkov, Industrial and civil engineering, 3 (2017) 